OBETS. Revista de Ciencias Sociales

Vol. 16, no 2, 2021, pp. 345-360

ISSN: 1989-1385

https://doi.org/10.14198/OBETS2021.16.2.08

\title{
GOVERNANCE AND STRUCTURING OF PUBLIC AND URBAN SPACE IN BILBAO: ANALYSIS OF GLOBAL TRENDS AT THE LOCAL LEVEL
}

\author{
GOBERNANZA Y ESTRUCTURACIÓN DEL ESPACIO PÚBLICO Y URBANO EN \\ BILBAO: ANÁLISIS DE TENDENCIAS GLOBALES A NIVEL LOCAL
}

\author{
Iago Lekue López \\ University of the Basque Country, Spain. \\ iago.lekue@ehu.eus \\ https://orcid.org/0000-0003-3752-162X
}

\begin{abstract}
Cómo citar / Citation: Lekue, I. (2021) "Governance and structuring of public and urban space in Bilbao: analysis of global trends at the local level”. OBETS. Revista de Ciencias Sociales, 16(2): 345-360. https://doi.org/10.14198/OBETS2021.16.2.08
\end{abstract}

C 2021 Iago Lekue López

Este es un artículo de acceso abierto distribuido bajo los términos de la licencia de uso y distribución Creative Commons Reconocimiento 4.0 Internacional (CC BY 4.0) https://creativecommons.org/licenses/by/4.0/deed.es

Recibido: 26/06/20. Aceptado: 22/01/21

\begin{abstract}
The phenomenon of deindustrialization, as well as the vertiginous changes dependent on fin ancial capital, produced new trends in the models of organization and production of western cities such as Bilbao. The socio-spatial organization and structuring of the 'new city' begins to be a topic of great importance. It is in this sense that the concepts of public and urban space take on greater theoretical relevance. The results obtained through the application of the theory in the case of Bilbao, follow global urban development tendencies. Spatial planning fulfils the strategic functions of a system that dominates urban processes at their convenience. There is a tendency to build aseptic spaces that are closer to the interests of capital than of citizens.
\end{abstract}

Keywords: Bilbao; public space; globalization; deindustrialization; gentrification; critical urban theory; urban regeneration.

\section{Resumen}

El fenómeno de la desindustrialización, así como los cambios vertiginosos dependientes del capital financiero, produjeron nuevas tendencias en los modelos de organización y producción de ciudades occidentales como Bilbao. La organización socioespacial y la estructuración de la 'nueva ciudad' comienza a ser un tema de gran importancia. Es en este sentido que los conceptos de espacio público y urbano adquieren mayor relevancia teórica. Los resultados obtenidos mediante la aplicación de la teoría en el caso de Bilbao, siguen las tendencias globales de desarrollo urbano. La planificación espacial cumple las funciones estratégicas de un sistema que domina los procesos urbanos a su conveniencia. Existe una tendencia a construir espacios asépticos que estén más cerca de los intereses del capital que de los ciudadanos.

Palabras clave: Bilbao; espacio público; globalización; desindustrialización; gentri cación; teoría urbana crítica; regeneración urbana. 


\section{INTRODUCTION: CONTEXTUALIZING BILBAO}

Socio-spatial transformations and arrangements are practically inherent to cities. In addition, as a rule, and even more in the Western world, they have been a reflection of economic changes and they have placed in different positions the social classes that inhabit the cities. Along with the governance tool, this has made urban and public space vary in form and content.

First of all, it is important to contextualize the city of Bilbao in recent history. At the end of the 70s, despite being the main service centre for the metropolitan area and the region, Bilbao was still fundamentally an industrial and port city. Taking the Ibaizabal estuary as its dividing axis, industrial activity focused mainly on the production of vehicles and transport material (18.5\%), basic metallurgical production (17.4\%), construction (14\%) and in metal constructions (13.1\%) (Atutxa et al., 2015).

Regarding the census of the Bilbao Metropolitan Area (BMA), which encompasses the 35 municipalities, counting that of Bilbao itself, in 1980 it had just over 955,000 inhabitants, more than $80 \%$ of the population of the province of Biscay. About half of the BMA population $(433,030)$ was located in the municipality of Bilbao, but this preference has been altered. According to the last population census of 2019 , the population is 346,843 inhabitants.

In addition to the de-annexation of some municipalities from the BMA, which caused a small population loss, we identified the de-industrialization that occurred in the 1980s, in the Biscay region, as one of the last major traumas for local socioeconomics, produced by the processes of economic restructuring and globalization. It should be noted that this process is subordinated to higher spatial scales, as early as it occurs under the demand of the European Union and with the approval of the Spanish Government and the submission of the Basque (regional) Government. Similarly, the response given to deindustrialization from the urban sphere is been characterized by previously satisfactory trends in other deindustrialized cities such as Pittsburg, Baltimore or Birmingham (Rodríguez, 2002). Thus, as if it were a sarcastic double-edge sword, globalization arises as a problem, and at the same time, as a solution.
After the depression produced by deindustrialization, they started to appear terms such as regeneration, renewal, revitalization or urban rehabilitation, that, as discussed below, have been nothing more than discursive ornamentation hidden behind a neoliberalization strategy. In this way, the Bilbao urban agenda was guided by megalomania and large urban projects, as a tool to reposition the city on the map and in the global city branding market.

Later we will analyse how the new city has reconfigured the spaces previously occupied by people, and in addition to giving up public space to private interests, it has produced such as fragmentation or duality phenomena. Giving rise to the territorial segregation and social inequality. These trends, aligned with the global ones, have produced a forced displacement in the Bilbao population. Taking the 'right to the city' (Lefebvre, 1969) as a touchstone of urban democracy, our objective is to clarify how the different trends produced by globalization are articulated and territorialized and in what way they affect the public and urban space of Bilbao. It is, therefore, of great interest to know how glocalization works (Beck, 2000; Brenner, 2003) under the logic of the urbanization of neoliberalism ${ }^{1}$.

\section{METHODOLOGY}

Our project aims to investigate the questions of 'how' and 'why' these changes have taken place in Bilbao. When the questions are these, it is necessary to carry out a case study methodology (Coller, 2005; Yin, 2009). This is based on the analysis of a specific situation, with the pretext of understanding the object of study and interpreting the differences with others. This method is guided more by objectives than by hypotheses, which ultimately would require an important theoretical framework in order to achieve its own analytical generalization. According to Yin (ibid.), it is an empirical investigation, which aims to place a real and contemporary phenomenon in its context, using reliable sources mostly based on good documentation and a case study database.

1 It refers to the context of urbanized formation of roll-out neoliberalism, in which cities have become strategic targets for neoliberal political experiments. They are granted an incubator role, for the main political and ideological strategies that allow the continuation of the neoliberal domain (Smith, 2002; Brenner \& Theodore, 2002) 
On the other hand, in this investigation, the case study will be unique, which means that it will not be multiple, nor will be carried out any other specific case study or diverse reality. In the same way, we must bear in mind that research must be focused on a system, a process, an institution, a social group or even a person. Indeed, studying the city model and the sociospatial planning of Bilbao fits perfectly with what is proposed. With that in mind, regarding data collection, Yin (ibid.) identifies six techniques: documentation, archival records, interviews, direct observations, participant observation and physical artifacts, which are summarized in three main sources of evidence: document analysis (including archival records), interviews and observation. Our study will be mainly based on the analysis of documents, but we must bear in mind that observation will be a continuously resorted resource. In this way, the empirical interpretation will be conditioned mainly by the theoretical framework, by the verification, through observation and the analysis of documents, of the urban dynamics explained in it. Consequently, in the empirical aspect, rather than in the interpretations of the agents, we will focus our attention on the identification of urban trends and processes that result in perceptible urban policies and interventions from which conclusions can be drawn.

Thus, in this case, is vital the analysis of documents through theoretical-analytical research, where the study of different works, articles and academic publications, allows to know new concepts, their different interpretations and also makes it possible to relate them to each other. This provides a further step to our research, since, in addition to the collection of information, this is interpreted forcing unique conclusions. Thus, technical reports, urban plans or communication campaigns may be studied under different prisms obtained through the aforementioned studies, but also through manifests, acts and others, from urban social movements or from Neighbourhood Associations.

It should be noted, the importance of authorship of these documents. Because there are differences between the interpretations of urban movements, of the academy, of institutions or of the press. That is why it is necessary to differentiate between the degrees of the sources. Firstly, the first-degree sources refer to books with original information, academic publications or official documents, and they also serve to establish the position that local and regional administrations have been adopting in urban matters in recent years. On the other hand, the second degree or secondary sources, are those that interpret or analyse the previous ones. Having clarified this, both sources will be used in the present study.

\section{ANALYTICAL FRAMEWORK}

The analytical framework that we have used for this analysis is based on the theories, methods and categories that Lefebvre argued, and goes through the most recent and relevant ontological assumptions about the urban as a whole (Harvey, 1973), towards a more reflective and updated of the context of planetary urbanization (Brenner et al., 2015). Aware of the possible theoretical magnitude, we have opted to make a brief journey through the classical and philosophical, towards the most contemporary trends.

\subsection{Lefebvre's epistemology of space as a forerunner of future urban theories}

We start from the premise that in the capitalist system space is produced in a technocratic and bureaucratic way in order to produce surplus value. That is, the space is consumed productively. In this general conception of space, we find the exception of public space as a space that transcends the merely physical, reaching the political-philosophical-communicational (Lefebvre, 1974). Lefebvre does not pronounce or make explicit the concept of public space. Now, it is true that, despite not using it, since at the time of publication of his works it was not widespread, it does reflect in different terms what could be understood as public space. At first, we find equivalence in the concept of social space. But in subsequent contributions, the social space of which Lefebvre (1974) speaks, ceases to be social to become specifically urban, since the majority of the population lives in cities, without appearing that the trend will change ${ }^{2}$. Thus, we must understand this space, as a

2 Basing on the thesis of Delgado (2013) we can understand how the primitive lefebvrian concept of social space with its three divisions explained below, becomes afterwards, in urban space, which has basically the same meaning. This chaining of words is the nearest notion to the concept of public space in Lefebvre's work. 
specific way of organizing and thinking about time and space in general, and not only in the physical framework of that material construction that is the city.

In La production de l'espace, Lefebvre (1974) establishes a division between three types of social space. First, Lefebvre identifies perceived space or spatial practice. This space refers to the most common events and happenings in life, to daily practices in the places of the social habitat (in which each individual, in a group, makes use of and practices that space). In this way, that determined use of space (which is, in turn, time and place) makes other types of practices impossible. According to Delgado (2013), in the context of a city, spatial practice refers to what happens in the streets and squares, the uses they receive from inhabitants and pedestrians.

Second, we find the lived space or spaces of representation. In this case, the spaces of representation are what turns physical spaces into places with meaning, that is, those that acquire images, memories and senses in the collective imagination. According to Delgado (2011), despite being a space for inhabitants and users, it is known for being more of artists, writers and philosophers who believe they are only describing it. In these spaces, there is the confrontation between the norms or rules of the powers, and the expressions of social life. It is ultimately 'the qualitative space of the submissions to the dominant representations of space, but also in which defections and disobedience drink and are inspired' (Delgado, 2013).

Finally, we find the conceived space or representations of space. It is surely one of the most debated and complicated concepts of Lefebvre, since he proposes that this space is the union and disunity of the previous two. On the one hand, it tries to reduce the spaces of representation into a space without content, without epic, turning what is lived only into what is visible. Thus, 'spatial transparency' is generated, which shows a social space, without highlights, surprises or public alterations. On the other hand, it seeks to generate a new perceived space, changing the shape of the space and altering its uses. In this way, the conceived space aims to be above the two spaces, moderating and containing the spaces of representation and generating or changing spatial practices.

So, we conclude affirming that the three spaces (perceived, lived and conceived) are the conceptual divisions of what is, today, the public space. Through this conception of public space, we will understand that, in addition to daily and planning space, this is also a space for confrontation, conflict and spontaneity. It is for this reason that urban infrastructures are required at the height of today's society, both in city centres and neighbourhoods. To the extent that space is not guaranteed or does not respond to social needs, the right to the city will not be guaranteed.

In this way, we discard that public space is only the street and the homeless areas between buildings, specialized spaces (such as museums) or areas called public spaces by legal mechanisms (Borja et al., 2003). Furthermore, 'public space is the city' and the city is with people, that is, with exchanges and relationships between people (ibid.). Habermas (1991) goes one step further and refers to the public space as an area where power is made visible. Thus, we affirm that space must be understood from a relational approach, we must assume that this is not only a container of social processes, but also is the result of the processes that take place in it (Khan et al., 2014). This produces its own structure and social morphology. In other words, people (physically, socially and mentally) build places, while places subjectify and objectify people as part of a multidimensional network.

\subsection{From epistemology of space to the ontology of the city: the emergence of new spatial settlement patterns and socio-spatial transformations in the context of rescaling of statehood}

During the last three decades, the loss of control that States exercised over many decisions in innumerable public policies, especially in the sphere of the European Union, has become evident. (Goikoetxea, 2018; Sassen, 1996). This clearly represents a separation from the decision-making power of the citizens, although from the point of view of the cities, the relative weakening of the State also opens up possibilities for management capacity for local and regional governments, producing an eventual scalar reconfiguration.

In this way, we highlight the ambivalence generated in cities after rescaling processes. Because, on the one hand, opportunities are generated to increase local autonomy, which may allow the strengthening urban democracy; but, on the other hand, there is the threat of dynamics that could promote uneven development. 
Understood as a product of the geography of capitalism, uneven (geographical or spatial) development refers to the differentiation of levels and conditions of spatial development (intra and inter-scalar) that occur due to the depreciation and increase of the land rents in different urban areas (going from the use value, to the value of change continuously from one area to another over time) and to the dialectic of differentiation and equalization of production conditions (territorial division of labour, compared to the universalization of working conditions) (Smith, 1984; Harvey, 2006). Thus, dominant and subordinate spaces appear, dependent on the movements of capital, which seeks to extract all possible economic profitability. In urban industrial capitalism, phases of uneven geographic development have been reproduced, since the last industrial restructuring led to a fragmentation of both the land and the work process (Soja, 2000).

Brenner (2009) points to uneven spatial development as one of the indicators of the advancement of 'actually existing neoliberalism', which refers to the historically specific regulatory frameworks in the territory and the evolution of the decisions made, against the advance of neoliberal strategies. Consequently, Brenner presents uneven development as a thousand-sheets, inasmuch as it has (different) consequences in each of the different socio-spatial dimensions ${ }^{3}$. On the other hand, it identifies the actors that produce and reproduce this phenomenon, among which the great institutional forms, such as the state itself, and various social forces, such as capitalist companies, unions, owners or local social movements, stand out.

In this context of destruction of existing institutional arrangements and political commitments, and creation of a new infrastructure for market-oriented economic growth, commodification, and capital domination (Brenner et al., 2002; Harvey, 2006), the socio-spatial forms of cities have been changing, producing new unknown categories until two decades ago. The phenomenon of deindustrialization, as well as the

3 These dimensions are four (Jessop, 2016): Place (linking social relationships to specific locations); Territoriality (delimitation, closure and subdivision of social relations); Scaling (vertical differentiation of social relationships); and Networking (transversal interconnections between geographically dispersed and organized locations). The set of these four dimensions would form what Brenner will call 'social space', which if we look at it, would complement Lefebvre's idea of it. dizzying changes dependent on financial capital or even on oil, produced new trends in the models of cities (Hobsbawm, 1962). These, also taking into account factors such as globalization processes, the emergence of information or knowledge societies, or new expansive urban forms, generated new theories around cities, e.g.: global city; informational city; ideopolis; fragmented city or postsuburbia, among others.

Similarly, glocalization (Robertson, 1992; Swyngedouw, 1997), was created to refer to the combined process of globalization and local-territorial reconfiguration. This implies the conflictive and dynamic restructuring, entanglement and re-differentiation of spatial scales. Thus, this diffusion in the scalar organization in capitalism makes the term glocal the appropriate one to explain the trends which imply different political strategies, to position certain subnational spaces (cities, regions ...) within supranational circuits (European or global) (Brenner, 2003).

In line with this, Sassen (1991; 1993) identifies cities as territorially specific urban places, in which decisive production and reproduction processes for globalization are developed, such as the financial services industries and transnational companies. In this context of work disaggregation and business decentralization, in post-industrial cities, service jobs (financial or not) have replaced manuals for the productive sector, which has led to a greater emphasis on consumption and well-being, rather than work. Thus, 'the values of consumption, rather than production, guide central city land use decisions' (Ley, 2003). This transformation of employment has been one of the pillars for the restructuring of cities in Europe, being in turn also one of the main factors causing inequality and urban fragmentation. These transformations in urban productive structures and in consumption orders hinder the incorporation of the poorest population sectors into the labour market, also complicating access to consumption.

Thus, we can affirm that urban, social and economic restructuring processes contribute to increasing social exclusion. On the one hand, due to the direct increase in unemployment, which includes the loss of purchasing power, the precarious situations and new forms of labour flexibility, but also due to the denial of access to relationships and the social fabric generated by both work and consumption. On the other hand, 
current job qualification levels are less achievable for many segments of the population, mainly due to socioeconomic conditions, and the decrease in social protection systems (Rodríguez et al., 2001 Moulaert et al., 2000). This context, caused by the lack of protection and social integration tools (whether institutional or not), also increases the risk of exclusion for workers in precarious situations and new forms of labour flexibility.

In direct relation to social inequality, there is a phenomenon in the new city ${ }^{4}$ that refers to the homogenization of some socio-spatial categories and activities in a concrete and physically and socially restricted space: urban segregation. This is based on the spatial concentration of a social class with homogeneous ethnic or socioeconomic conditions in a specific territory, creating a social differentiation with the rest of the urban socio-spatialities.

According to the aforementioned, Blanco and Subirats (2008) exposes certain variables to understand the consequences of social inequality and territorial segregation in cities, and the results they produce:

Table 1. Urban trends depending on the values: "Social inequality" and "territorial segregation".

\begin{tabular}{|c|c|c|c|}
\hline & & \multicolumn{2}{|c|}{ Territorial Segregation } \\
\hline & & Low & High \\
\hline \multirow{2}{*}{ Social Inequality } & Low & Inclusive cities & Fragmented cities \\
\hline & High & Inequal cities & Exclusive cities \\
\hline
\end{tabular}

Source: Derived from Blanco et al. (2008; 2018).

We do not necessarily have to think in terms of cities, it is also applicable to trends in different neighbourhoods or urban areas. In the case of inclusive cities, both segregation and inequality are moderate. This assumes that different social groups, of different incomes, ethnic groups or subaltern identities coexist in a common space. The opposite trend would be that of excluding cities. In this case, a high territorial

4 We refer to the new city as a metaphor for the postmodern city. This is characterized by urbanism based on aesthetics, uncontrollable and chaotic, far from modernist urbanism based on reason and with social objectives (not necessarily class). Thus, postmodernist flexibility is dominated by fiction, fantasy, the immaterial, fictitious capital, images, transience, chance, and flexibility in production techniques, in labor markets, and in consumer niches (Harvey, 1990). segregation, together with a high inequality, causes an exclusive and exclusionary use of public space. Given that, the polarization of society, stimulates the creation of different centralities within the cities, likewise differentiating a public space for the best socially positioned groups -they are generally the elites that carry out urban policies- and other spaces -owned by sheer necessity-for the excluded.

We will stop, as a compilation, in the concept of fragmented city or fractal city (Soja, 2000). According to Marmolejo and Stallbohm (2008), it is characterized by a monofunctional specialization in the use of land and by the low hierarchization of urban space, hindered, in turn, by barriers and important urbanized spaces. In addition, we must add a lack of beauty or physical attractiveness. The fragmented city makes a direct allusion to the normalized and staged differences in the urban space between social classes. These tend to greater territorial segregation, but not as much social inequality, moreover, social inequality at the total level may not be very high, but it may be clearly staged depending on urban areas.

With that in mind, they identify four dimensions in which these characteristics become visible. First, they expose the physical dimension, that is, the existence of natural and artificial architectural barriers. The second dimension is the social one, in the sense that public spaces and spaces for interaction between people have been replaced by individual warehouses (such as shopping centres) or residential buildings (because, in monetary terms, it is more efficient to build blocks, than places). Thirdly, we find the environmental dimension, in which the damages produced by an expansive urbanism or sprawl stand out, this damages the operation of rural, agricultural and natural spaces. Finally, in the economic dimension, specialization in a single area or sector causes impoverishment and dependency in the city's economy.

Once these concepts have been explained, we understand that the concept of global city worked by Saskia Sassen (2001), who summarizes global cities through various characteristics, may be interesting. In the first place, this city model stands out for hosting different headquarters (accounting, taxation, public relations, research...) of multinationals, their subsidiaries and subcontracted companies, a direct effect of globalization. These companies often offer 
specialized products and services, largely related to the electronics industry or to the 'production of the most important information industries'. On the other hand, these cities no longer work like the capitals of former empires, in conflict with the rest and individually, but create networks between them, leaving behind possible dependence on their national economies.

Likewise, global cities more than places, they are processes (Castells, 1996), characterized by socioeconomic and spatial inequality. The one that causes, together with the aforementioned, the formation of different centralities; where large sectors of global capital are concentrated, and in turn, a group of excluded (exploited women, ethnic-religious minorities, immigrants...), who (re)provoke a great contradiction and confrontation, and which in many cities had tended to forget. Consequently, Sassen (ibid.) concludes that global (and globalized) cities organized in a transnational network, exchange information at all levels (politics, economy, defence...) and again become a focus of struggle and protest against inequality between classes and spaces.

\subsection{Present futures and threatening trends: gentrification and touristification}

First of all, we want to bring up the debate on gentrification. It is a controversial concept that began to be studied in the past 20th century, giving rise to two great theories, which a priori seemed to be in conflict, but which have subsequently been found compatible. On the one hand, there is the theory of David Ley (1996), who established the bases of gentrification in the importance of demand. In other words, he proposed that gentrification was a phenomenon exclusively dependent on the actors interested in returning to the city centres from the neighbourhood-suburbs in which they lived. With a young, well positioned economically, single and predominantly white profiles, they would be motivated by the increase in jobs in the new financial centres of downtown.

Faced with this position, Neil Smith (1979) turned his attention to the supply. This conceptual approach implies giving greater weight to structural economic factors than to agency ones. Thus, the main gentrifying actors would become those with the ability to influence the real estate market, among which credit institutions, large property developers and construction companies stand out. In this sense, the variability of land value in the capitalist system is taken into account. Since, depending on the cycles of use, there is a depreciation of capital and finally an abandonment of the area. This increases the rent-gap ${ }^{5}$, that when it is wide enough, the various groups of actors in the land and housing market, can initiate gentrification in a given neighbourhood, producing cycles of the aforementioned creative destruction of neoliberalism (Smith, 1979). Smith (ibid.) also points the rehabilitation of neighbourhoods as the main risk factor, either by private or public initiative. This happens where rent-gap has occurred, and usually appears in neighbourhoods near the city centre. Likewise, we highlight five characteristics that influence gentrification: 'the transformed role of state, penetration by global finance, changing levels of political opposition, geographical dispersal, and the sectoral generalization of gentrification' (Smith, 2002; Lees et al., 2016).

So, we take a current definition and in accordance with what has been presented so far:
The investment of capital at the urban centre, which is designed to produce space for a more affluent class of people than currently occupied that space... Gentrification is quintessentially about an urban reinvestment. In addition to residential rehabilitation and redevelopment, it now embraces commercial redevelopment and loft conversions (for residence or office) as part of a wider restricting of urban geographical space. (Smith, 2000).

As we said before, it is evident that the gentrification theory is not a fixed and exportable model, since, in areas of the global south, regions of Asia, the United States or Europe, the conditions and processes are different, so it is it is difficult to make a comparative urban planning (Lees, 2018). On the other hand, there are gentrification processes led by different reasons and actors, such as art-led gentrification ${ }^{6}$. Despite this, Betancur (2014) establishes certain structural conditions that are repeated at a global level, such as the

5 This will fluctuate basically by differentiating between devalued capitalized land rent and a high potential land rent.

6 Despite the fact that all gentrification processes are subject to capital-led, which is ultimately the only necessary condition, making the rest of the actors mere consumers or conjunctural subjects. 
restructuring associated with changes in social regimes (from modernity to postmodernity or from industrial to post-industrial society), and comparative factors such as the production of gentrifiers, gentrifiable areas, average rental incomes or the displacement of social classes. It also highlights the role of transnational elites, de-virtualized in local industries, whose objective is to take over land and properties in order to carry out profitable tourism projects (Lees et al., 2016).

Certainly, one of the consequences of gentrification is touristification. Although it is far from the only reason why touristification appears, both processes are crossed (Cocola-Gant, 2018). The truth is that gentrification usually encourages the promotion of a space (Judd, 2003). In this way, clean spaces are created with consumption opportunities, where the middle class finds its ideal place. It is in this context, in which the value of the land increases (through the new consumption spaces), establishing the breeding ground for tourist speculation by the owners.

As we have been saying, the appearance of both tourism and gentrification must be considered as the consequence of the same process of economic and spatial restructuring in which changes in the political economy of cities have been accompanied by changes in consumption and employment patterns (CocolaGant, ibid.). In this way, the gentrification caused by tourism produces three forms of displacement (ibid.): residential displacement, commercial displacement and place-based displacement. The first refers to the increase in the value of the land by the exploitation of the use of the land for commercial and tourist purposes. This causes house prices to increase, on the one hand, making it difficult for residents who previously inhabited that place to stay, and on the other, making it easier for wealthier residents of other urban areas to move to the neighbourhood in question. In addition, the appearance of housing for tourist use is growing, especially in degraded areas in which hotel companies (or companies like AirBnb and so on), rehabilitate entire buildings with the aim of making their use profitable, producing again an upward trend in house prices and excluding directly their residential use to neighbours (Brossat, 2018).

Secondly, commercial displacement is based on the transformation of consumption establishments. Under the demand of new visitors, local traditional shops and their workers must make room for souvenir shops, restaurants, pubs, and other businesses redesigned for leisure. Thus, local businesses, which are not able to pay the new rental prices, are replaced by franchises.

Finally, we introduce the place-based displacement. This refers to the feeling of dispossession of 'their' space that residents feel in the touristification processes. Thus, the places that defined the residents of a neighbourhood become spaces that they no longer associate with themselves (Davidson, 2008; Davidson et al., 2010). So, community areas such as public spaces, local shops or the street itself, that is to say, places of daily transit where relations between neighbours took place, are reduced. In the case of public spaces, it is even more dramatic, since they become commercial areas, making meeting spaces for long-term-residents disappear (Haussermann et al., 2003). In addition, several tourist destinations, especially those related to cruise tourism and mass tourism, have experienced a loss of environmental quality, due to waste, air or noise pollution, which directly affects the quality of life of the residents themselves (Colomb et al., 2016).

Bélanger (2007) reflects on the relationship between tourism and gentrification, and the loss of public space and its quality. If we pay attention to what was presented at the beginning of the article, we verify that space is the image perceived through the daily life of residents and the representation that this has around their lives. But tourism, through its market and sometimes with the help of institutions (at all scales), generates another image through city branding.

Public spaces are a key piece in the development of city brands. That is why we consider it appropriate to end this section with the following reflection:

\footnotetext{
In public spaces, authorities justify/legitimate their actions and their commitment to their residents, investors and visitors by planning, revitalizing and shaping the urban environment. These actions could be the creation of new public spaces as well as redesigning, rehabilitating and revitalizing existing ones. In their branding strategies, authorities try to create a new (positive) image and do not hesitate to highlight public spaces. [...] Many authorities' efforts to sanitize/homogenize public spaces through design, programmed uses, activities and exclusion (or harassment) of more marginal populations seems to reflect the goal of satisfying the preferences of tourists, investors and workers, and showing consideration for their 'sensibilities' (Lofland, 1998; Vlez, 2004). (Bélanger, 2007; 6).
} 


\section{BILBAO AND THE NEW URBAN SPACE DYNAMICS}

It is said that, to read the city, you have to go through it, and that is what we have tried to do, walk through it, live it and compare it with that of years ago, and with the incessant renewal of dynamics, concepts and categories that are emerging from the critical urban theory. From our point of view, it is worth to outline the transversality of 'public space' concept. It is in fact, the common thread of the article and, as it has been mentioned, a point of social pressures, the political arena where different economic and urban ideas confront each other. For this reason, as detailed below, we will look at the analysis of the concepts, with the intention of understanding the orientation that Bilbao is taking, to check after all, if the aforementioned loss of public space and its quality has been produced or not.

\subsection{Uneven Spatial Development}

As we mentioned at the beginning of this article, industrialization led to uneven development in many European cities, and the case of the BMA was no exception. Until the 1980s, and even nowadays, the two margins separated by the Ibaizabal and that formed Bilbao, were the live characterization of the differences between classes and origins. The (Spanish origins) working class confined to the left bank was the muscle that nourished Bilbao's heavy industry. In front of it, on the one hand, the Basque business and financial bourgeoisie occupying the areas on the right bank and the urban centre itself, and, on the other hand, the postFrancoist residual political class, which was located in large houses on the right bank.

In this way, we verify that the moments of development of capitalism are associated with the creation of different socio-spatialities in certain places and territories. (Brenner et al., 2011). But it is also true that these landscapes of inequality do not persist forever. The uneven development of capital is dynamic (Harvey, 1982), which allows us to explain how, after the decline of the Bilbao industry in particular, and Biscay in general, the land where the factories were located was devalued. Thus, industrial spaces such as those of Abandoibarra (where the Guggenheim is currently located) and Euskalduna, were the object of profitable speculation, since they occupied a central place in the 'New Bilbao'. So much was the interest of the institutions in revaluing the lands of this area, that they forgot the demands of the peripheral neighbourhoods. In this way, public investment focused on creating consumption spaces, with luxury hotels, exclusive homes, museums and shopping centres, decreasing public investment in infrastructure for non-central neighbourhoods (Vicario et al., 2003).

We conclude by affirming that the industrial decline, and the subsequent economic restructuring, have contributed to increasing the spatial and social differences in the entire metropolitan area. Thus, the new labour and demographic dynamics have favoured the conditions for the reproduction of uneven development (Rodríguez et al., 2001). We also validate the thesis that confirms the close relationship between the spatial structure of the city and the transformations of the productive system (Topalov 1984; Massey, 1984). At the same time, we consider uneven geographic development as one of the main facilitating conditions for the dynamics that have subsequently occurred in Bilbao, such as fragmentation.

This fragmentation would be showed by the four dimensions previously cited, that are fulfilled to a certain extent in Bilbao (Annex A). Firstly, the ones that used to be common, natural and artificial architectural barrier, slightly remains in neighbourhoods like Rekalde. Indeed, after a Union Plan of the bordering neighbourhoods of Amezola, Irala and Rekalde, which was supposed to rehabilitate the three areas, solely renewed first one, leaving Irala and Rekalde still with old industrial pavilions and projecting a mental barrier of separation. Most visual could be the commonly known 'Railways sea' (Mar de vias), the train station that separates Bilbao La Vieja with Abando. The second dimension refers to the loss of public spaces, as we will see, there are countless cases in Bilbao of appropriation of public space for events and consumption, but we would like to take as a reference the trail that is held on the first Saturday of each month in Bilbao La Vieja, the 'Alternative Trail on May 2 Street'. The aforementioned is the neighbourhood with one of the highest rates of foreigners $^{7}$, but once a month, the part closest to the estuary, stops being multiracial, to be crowded with

7 The population of foreign nationality in the municipality of Bilbao in 2018 was $8 \%$ on average, a low percentage when compared to $27 \%$ in the San Francisco neighbourhood or $15 \%$ in Bilbao La Vieja. 
white people looking for bargains to buy. The market itself means, therefore, that on the one hand this public space is used under a consumerist logic (since they are areas that have a lot of community life), and, on the other hand, the reality of the neighbourhood is distorted. Thirdly, the expansive urbanism can be noticed in Bilbao, although it is true that the peripheral neighbourhoods (and those denied from cultural attractiveness) are less taken into account in the cycles of capital, the municipalities adjacent to Bilbao in old rural areas are becoming new areas of expansion, as shown by the population growth of Leioa, a municipality located nine kilometres from the city. It should also be noted how the extensions of the Loiu Airport (Bilbao), gain ground to the rural area. Finally, the specialization in a single economic sector is turning Bilbao from an industry dependent economy, to a services dependent economy as discussed below.

\subsection{Employment, precariousness and the change of economic model}

We focus our attention on the municipality of Bilbao, but without losing sight of its Metropolitan Area. We take the centre of Bilbao as flagship of the desired change, and the neighbourhoods that surround it instead, as the hidden. The triumph of aesthetics over ethics that supposes the transition from modernism to postmodernism, or from Keynesian-Fordism to flexible accumulation, has brought the weakening of unions, the atomization of work in individualized productive units, and the displacement of factory employment to the service sector.

This new paradigm reduced the social and political power that traditional workers' institutions had had (Harvey, 1990). To contextualize, in the region of the Basque Country, union membership in the salaried population was $25.6 \%$ in 2004 , a period of economic prosperity prior to the crash of 2008. In fact, after the financial crisis, the situation doesn't get better, barely reaching $22 \%{ }^{8}$ union membership in 2016 . The opening dialogue of the film "Sorry we missed you", directed by Ken Loach and Paul Laverty, faithfully

8 Data extracted from the report presented by the Basque Women's Institute (Emakunde) in 2017. Available at https:// www.emakunde.euskadi.eus/contenidos/informacion/servicio_ cifras/es_emakunde/adjuntos/cifras_2017.pdf. Accessed and retrieved: June 10, 2020. summarizes the current scenario. The film begins with a job interview for a delivery company, and after admitting the protagonist, a head of household, to the job, the interviewer explains the company's policy as follows:

Let's just get a few things straight at the start, though, shall we? You don't get hired here. You come on board. We like to call it on-boarding. You don't work for us. You work with us. You don't drive for us. You perform services. There's no employment contracts. There's no performance targets. You meet delivery standards. There's no wages, but fees. Is that clear? [...] No clocking on. You become available. You sign up with us, you become an owner driver franchisee. Master of your own destiny, Ricky. Sorts the fucking losers from the warriors. You up for that?

In Bilbao, the fundamental reorganization of the urban economy occurred in the 1980s. It is at this time that the city's manufacturing specialization tends to focus on services.

Table 2. Employment distribution by industry in Bilbao.

\begin{tabular}{l|r|r|r|r|r|r|r|r|r|r|} 
& 1981 & 1986 & 1991 & 1996 & 2001 & 2006 & 2011 & 2016 & 2017 & 2018 \\
\hline Agriculture & 0.2 & 0.23 & 0.32 & 0.32 & 0,37 & 0,43 & 0,42 & 0,34 & 0.22 & 0.07 \\
\hline Manufacturing & 33 & 28.69 & 25.66 & 21.94 & 16.55 & 14.25 & 11.07 & 10.27 & 13.52 & 14.1 \\
\hline Construction & 7.4 & 5.57 & 6.95 & 6.14 & 8.34 & 9.51 & 7.42 & 5,65 & 5,26 & 5.24 \\
\hline Services & 59.4 & 65.5 & 67.08 & 71.6 & 74.73 & 75.82 & 81.09 & 83.74 & 81 & 80.58 \\
\hline TOTAL & 100 & 100 & 100 & 100 & 100 & 100 & 100 & 100 & 100 & 100 \\
\hline
\end{tabular}

Source: Derived from INE (Instituto Nacional de Estadistica) and Eustat (Basque Statistics Office) data.

In addition to this evidence, we must bear in mind that the reorganization also brought about a readjustment in the unemployed population. In 1975, the unemployment rate stood at $2.5 \%$, this figure would rise to 26 points in 1986, and would hardly change until the end of the 1990s, which fell to 16 points. After falling the first years of the new century, the 2008 crisis raised the figure to almost 20 points. But quickly, in a few years, it has managed to stabilize it at $13 \%$.

We attribute this speed of response to the informalization of labour relations and precariousness. This strategy, comparable to the German minijobs, thanks to which the unemployment rate remains low, only impoverishes the workers, institutionalizing vulnerability and increasing the risks of exclusion. Ultimately, we highlight the proliferation of delivery 
or home delivery companies (Uber, Deliveroo, etc.), which undermines the bonds of solidarity and security between workers through individualization (Rodríguez et al. 2001).

\subsection{Gentrification and tourism: two phenomena that feed each other}

We conclude with a reflection on the gentrification process that is taking place in Bilbao. Several authors have identified the conditions and the first characteristic episodes of the processes of gentrification and touristification (Atutxa et al., 2015; González, 2004; Rodríguez, 2002; Vicario et al., 2003). All of them are currently concentrated in the Bilbao La Vieja area, and in general throughout the Old Town. Although the majority of institutional efforts today are focused on converting the La Ribera-Zorrotzaurre peninsula into an island, collapsing the factory vestiges, displacing its inhabitants residentially and evicting alternative cultural centres with the aim of generating an 'island of knowledge'. We could point here to a process of neohaussmannization, since obsolete land, bought by public institutions, is being sold for a low price to the real estate sector.

Located in the historic centre of Bilbao, these areas have been identified as 'opportunity areas' by the institutions and private entities that are working on the remodelling of the new city. This public-private binomial is staged through a partnership ${ }^{9}$ led by Bilbao Ría 2000 as manager, and Bilbao Metropoli-30 as developer, and is, in most cases, the leader of all the most important urban regeneration projects. This in turn shows an institutional weakness, since it has to resort to co-financing formulas to carry out the projects.

Despite this, in the same way that occurred in the Abandoibarra area, in Bilbao La Vieja and in the Old Town, it is recognized that gentrification has been largely policy-led (Rodríguez et al., 2015), it is that, is has been directed, devised and designed by the institutions and to their liking. The commitment made by the institutions to promote art, culture and tourism has forced the demolition and reconstruction of the mentioned areas. All this, under the pretext

9 Both Ría 2000 and Metropoli-30 are associations made up of local and regional political institutions, with the participation of these and public entities, in addition to private companies such as banks. of producing spaces for people with more economic resources than those who inhabited that place. In any case, appealing to the global city, cosmopolitanism and inter-city competitiveness ${ }^{10}$, seems to legitimize regeneration and transformation plans.

We also identified a threat in commercial gentrification, since one of its main consequences is the evanescence of traditional local commerce, in exchange of the emerge of shopping centres, franchises and financial or speculative projects. The case of the Ribera food market is interesting, located between the Old Town and Bilbao La Vieja, which we identify as a consumer space with low added value logics and with low purchasing power customers. It is a space with ideal conditions for socio-spatial transformation, in turn fed by the general gentrification process that the entire area is undergoing. In addition, it should be noted that, thanks to its recent reform in 2010, this place has undoubtedly become a new opportunity area. This could be proved by the irruption of BBK ('Bilbao Biscay Savings Bank' for its acronym in Basque), which has located his centre for developing innovative projects in 'Casa Cuna', a historical building situated just in the heart of Bilbao La Vieja.

Processes such as those mentioned, which not only appear in global cities, but also in regional capitals that seek to reposition themselves in the global economy, promote the emergence of tourism as a dependent productive sector to which prostrate with the intention of positioning the city in the market of cities. As the City Council states, Bilbao has gone from being an industrial city to being a tourist destination. This implies, a commitment not only for the third sector in general, but specifically for the tourism sector. For years, tourism has grown by leaps and bounds in the town. Below, we present some of the factors that we consider influential for the touristification of an area.

In the first place, it is necessary to verify the constant and gradual increase in the number of tourists ${ }^{11}$, which in 2005 stood at 550,264 travellers and in 2019 is already close to one million $(992,890)$. This increase, on the other hand, has led to an increase in the supply of accommodation in the city. If in 2014

10 Bilbao was recognized with the 2018 Best European City Award.

11 Data provided by Eustat. 
we found 96 hotel establishments, there are currently about $130^{12}$, most of them located in the economic centre and the old town. In this sense, we also highlight the rapid expansion that the AirBnB company has had in Bilbao. Given that, in two years, from 2016 to 2018, the offer of tourist flats has almost tripled, going from 308 to $896^{13}$. We can confirm that this upward trend continues, since the company itself figures in $400 \%$ the increase of tourist housing reserves in the city ${ }^{14}$. On the other hand, the emergence of 'capsule hotels' (like those famous in Japan) in Bilbao, demonstrates once again the city's alignment with global trends and neoliberalization itself. Similarly, the fact that the institutions have chosen to compete in the city market and seek to project the image of Bilbao to the rest of the world, has led to an increase in the holding of major international events. Examples include the EMA (European Music Awards from MTV), the 'European Champions Rugby and Challenge Cup' rugby finals or the Red Bull Cliff Diving World Series, all held in 2018.

As has been shown, tourism has an increasing weight in the Bilbao economy, but this, of course, not only affects the economy, it also has its consequences at the urban level. We must be aware that all these factors, such as the existence of high rises in rental prices, are causing a place-based displacement of residents in gentrified or touristified areas, denying them membership in the community and distorting the space built by themselves ${ }^{15}$. On the other hand, it is paradoxical that all the actions and events of great significance in the city are carried out in the most central areas, thus forgetting the other neighbourhoods. And in the cases in which events are held in the most peripheral or degraded neighbourhoods such as Bilbao La Vieja or San Francisco, the organizers forget their inhabitants. Thus, these neighbourhoods are taken and occupied by its picturesque image, to offer a cultural model based on consumption leisure.

But, leaving aside the exceptions, it is usual to keep away the attractive events and events of interest

12 Data provided by Eustat, and geolocated thanks to its 'LurData' software.

13 Data provided and verified by DataHippo.

14 In this way, Bilbao occupies the second position in the "trend destinations" list that the company makes for this 2020.

15 There are multiple complaints on this issue made by the Old Town Tenant Union (AZET for its acronym in Basque). in these neighbourhoods. As an example, we will take the program of the White Night 2019 that commemorates the anniversary of the city. In this case there is no special influence and intrusion of private companies, but the abandonment that exists towards the neighbourhoods is striking. The totality of the light, magic, music, acrobatics or painting shows are distributed between the Old Town, Abando, Indautxu and the University of Deusto (the latter being the only place in Deusto's neighbourhood highlighted). In this way, neighbourhoods such as the well-known Otxarkoaga, Rekalde, Basurto, Miribilla or Amezola (neighbourhoods that are quite different between them in terms of income and centrality) are omitted. It is worth reflecting on the inhibition that this type of event implies for the inhabitants of these neighbourhoods, since in a certain way, they are not directed at them.

Finally, according to Smith (2017), these events represent the securitization of the city. On the one hand, this process reproduces the idea of creating a city brand. It is about the public space in question being a showcase and demonstration of the organization and tidiness of the city, that is, the essential crown jewel. This implies the disappearance of the conflict in these spaces, since they break with the prestigious harmony that is sought to primarily satisfy tourists and visitors. On the other hand, as a consequence of this, security, vigilance and restrictions increase, to the detriment of spontaneity and non-normative.

Gentrification, along with touristification, exhibits at least three characteristics of globalization in Bilbao in terms of gentrification theories: active participation of the government (local, regional and national) in gentrification through institutional-business activities, affluence of global funds due to the tourism industry and new spatially strategic business returns, and the gentrification of several urban areas simultaneously. Mainly due to the relationship with financial capital, gentrification at small to medium-sized sites bears a close resemblance to similar processes at larger locations, reaffirming the theory of planetary gentrification (Lees et al., 2016).

\section{CONCLUSIONS}

The process of studying an urban piece as important and significant as Bilbao, requires a recognition of the actors who exert pressure on the territory and 
the areas of power that may exist when planning the city. In other words, it is obviously in the sphere of governance where the urban and public space is really produced, where the guidelines for urban planning are used and where the most evident power relations took place. In this research we do not really identify those responsible agents or interactions, with the exception of specific examples and with the aim of making an accurate diagnosis of the socio-spatial reality of Bilbao, presenting only the results of governance itself.

We pick up the words of Lefebvre (1970) and Topalov (1979) in which they stated that urbanization was supplanting industrialization as the driving force of capitalist expansion through private processes of appropriation of spaces, now this is truer than ever. Western cities -and many of the large and mediumsized cities of the east located in developing countries such as China or India- no longer base their economy on mere industry, but on the productive industry of urban planning, making it the main sector of the urban economy.

We would like to conclude briefly by taking up the right to the city. We have explicitly evidenced the social segregation, mainly by income, but also by ethnicity, which exists in Bilbao. Thus, we deduce, after analysis, that the city oscillates between the fragmented city and the excluding city. At the same time, we can confirm, categorically, that the public space of Bilbao, rather than suffering a loss as such, is being domesticated. Mercantilisation and the consumerist model, the proliferation of non-places, the increase in social control and the fragmentation trend, in the context of current glocalization, have contributed, as demonstrated, to building aseptic spaces that are closer from transnational capital interests, than from citizens. Thus, global trends are staged in different neighbourhoods, in the city's own duality and in the gentrification processes that are taking place.

The right to the city needs institutions and local governments to guarantee it. Just as gentrification, urban regeneration and socio-spatial transformations have a very significant main actor (multi-scale public institutions), the right to the city also requires them to be carried out. The state, as a local and regional public institution, must value 'sustainable development' as a meeting place between productive activities and natural environments; 'shared prosperity' as a logic of dialogue between economies and social cohesion; and 'coexistence habitability' as a proposal for the intersection between ecology and daily well-being (Blanco et al., 2018). Thus, it would be a question of making socio-spatial justice effective, which we understand, includes social justice, economic and less mentioned, but equally important, environmental.

Finally, we would like to end by remembering that there are urban alternatives, which, as Harvey (2012) explains, go beyond the social demand of the right to the city. These alternatives refer to a process of urban revolution that, according to the author, must be staged by occupying the most significant public spaces, that is, with more symbolic burden, turning these into a common political good. Harvey (ibid.) Also stresses that the occupation of a public space through collective power is the most effective instrument of opposition when the windows of opportunity at the institutional level are closed. It identifies the process of neoliberalization of the city as an urban revolution carried out by capital, and claims the option of a new urbanism with a revolution contrary to it (counterrevolution), giving back spaces, and the right to occupy them, to all persons. This happens by returning all power to the city, and to the people who live it. Far from the neoliberal 'There's no alternative', established and rooted as a Lefebvrian consensus by Bilbao urban thinkers, from the lived and perceived space there are other rhythms, and it seems that there are also different alternatives to the model proposed as conceived space. The debate is now, to choose to win the space conceived in order to build hegemony, or to build alternatives in and from the previous spaces to fight the model of the space conceived. 
ANNEX A: PLAN OF THE NEIGHBORHOODS AND MENTIONED URBAN ELEMENTS

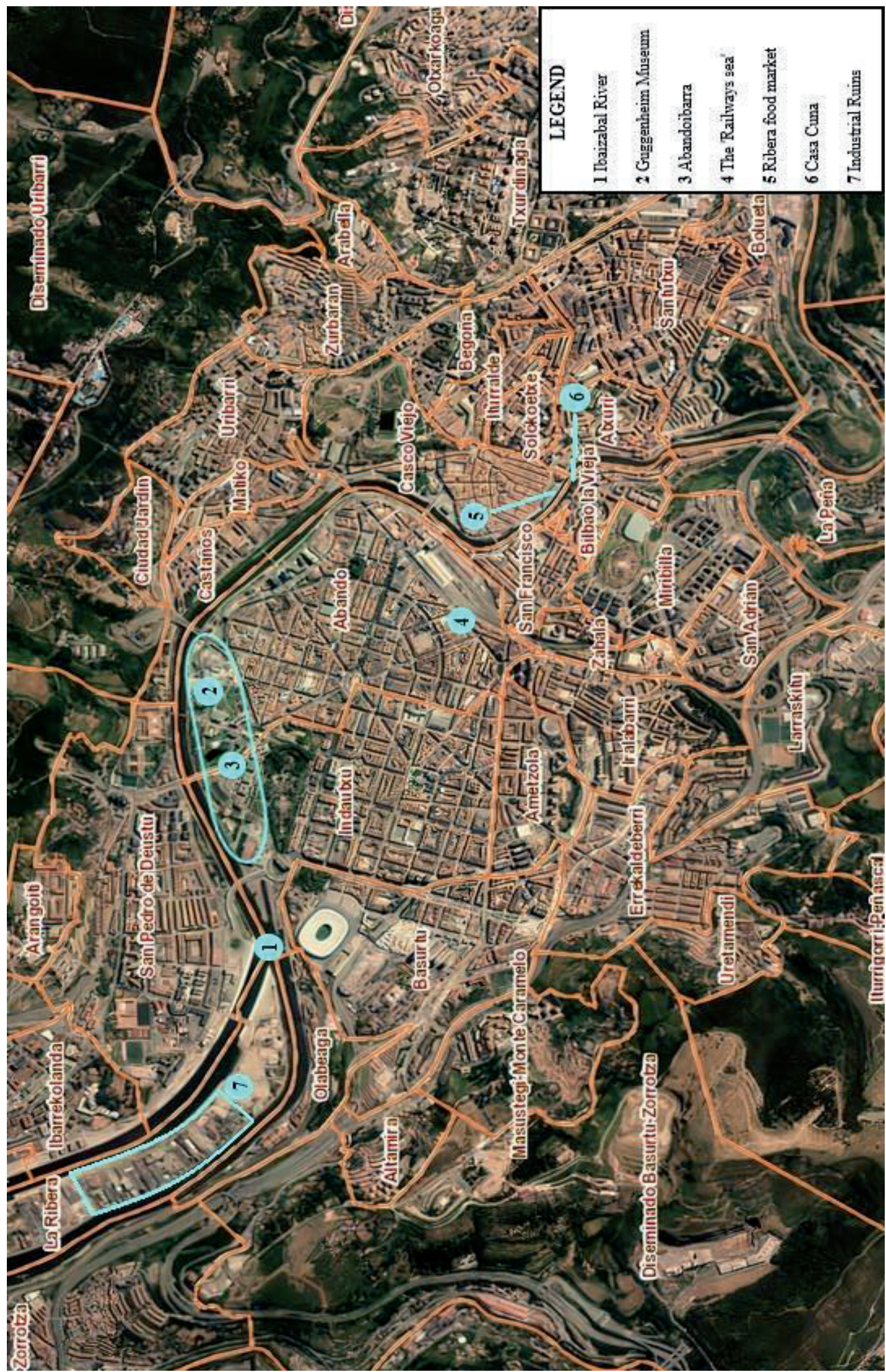

Source: Own elaboration based on LurData-Eustat Geographic Information System. 


\section{BIBLIOGRAPHIC REFERENCES}

Atutxa, E., Campelo, P., Izaola, A, Urrutia, V. \& Zubero, I. (2015). Bilbao: en la búsqueda de nuevos modelos de ciudad. In Martí-Costa, M., \& Subirats, J. Ciudades y cambio de época: discursos sobre politicas urbanas y crisis en España. Políticas urbanas en el escenario 2015. Bilbao: Servicio Editorial de la Universidad del País Vasco

Beck, U. (2000). What is globalization?. Cambridge: Polity.

Bélanger, H. (2007). Public Spaces in Gentrifying Neighbourhoods: Conflicting Meanings?. ENHR 2007 International Conference 'Sustainable Urban Areas'.

Betancur,J.J. (2014). GentrificationinLatinAmerica:Overview and Critical Analysis. Urban Studies Research, 2014, 1-14. https://doi.org/10.1155/2014/986961

Blanco, I., Gomá, R. \& Subirats, J. (2018). El nuevo municipalismo. derecho a la ciudad y comunes urbanos. Gestión y análisis de políticas públicas, 20, 14 - 28. https:// doi.org/10.24965/gapp.v0i20.10491

Blanco, I. \& Subirats, J. (2008). Social exclusion, area effects and metropolitan governance: a comparative analysis of five large Spanish cities. Urban Research \& Practice, 1, 2, 130 - 148. https://doi.org/10.1080/17535060802169823

Borja, J. \& Muxí, Z. (2003). El espacio público: ciudad y ciudadanía. Barcelona: Diputació de Barcelona.

Brenner, N. (2003). 'Glocalisation' as a state spatial strategy: urban entrepreneurialism and the new politics of uneven development in Wester Europe. In Peck, J. \& Yeung, H. (eds.) Remaking the Global Economy: Economic geographical Perspectives. London: Sage.

Brenner, N. (2009). A thousand leaves: notes on the geographies of uneven development. In Keil, R. \& Mahon, R. (eds.). Leviathan Undone? Towards a Political Economy of Scale. Vancouver: University of British Columbia Press.

Brenner, N., Peck, J. \& Theodore, N. (2011). Neoliberal Urbanism: Cities and the Rule of Markets. In Bridge, G. \& Watson, S. (eds.). The New Companion to the City. 15 - 25. Oxford: Blackwell-Wiley. https://doi. org/10.1002/9781444395105.ch2

Brenner, N., \& Theodore, N. (2002). Cities and the geographies of 'actually existing neoliberalism'. Antipode, 34 (3), 349 - 379. https://doi.org/10.1111/14678330.00246

Brenner, N. \& Schmid, C. (2015). Towards a new epistemology of the urban? City, 19, 2-3, 151 - 182. https://doi.org/10. 1080/13604813.2015.1014712

Brenner, N. \& Schimd, C. (1996). Information age: Economy, society and culture. Oxford: Blackwell.

Brossat, I. (2018). Airbnb, la ville ubérisée. Montreuil: la Ville brûle

Castells, M. (1996). Information age: Economy, society and culture. Oxford: Blackwell.

Cocola-Gant, A. (2018). Tourism gentrification. In Phillips, M., \& Lees, L. (eds.). Handbook of Gentrification Studies. Edward Elgar Publishing. https://doi.org/10.4337/97817 85361746.00028

Coller, X. (2005). Estudio de casos. Madrid: Centro de Investigaciones Sociológicas.
Colomb, C. \& Novy, J. (2016). Urban tourism and its discontents: an introduction. In Colomb, C. \& Novy, J. (eds.). Protest and Resistance in the Tourist City. 1 - 30. London: Routledge. https://doi. org/10.4324/9781315719306

Davidson, M. (2008). Spoiled mixture: where does state-led 'positive' gentrification end? Urban Studies 45, (12). 2385 - 2405. https://doi.org/10.1177/0042098008097105

Davidson, M. \& Lees, L. (2010). New-build gentrification: its histories, trajectories, and critical geographies. Population, Space and Place 16, (5). 395 - 411. https://doi. org/10.1002/psp.584

Delgado, M. (2011). El espacio público como ideología. Madrid: Libros de la Catarata.

Delgado, M. (2013). Espacio público como representación, espacio urbano y espacio social en Henry Lefebvre. A Cidade Resgatada: Ordem dos Arquitectos - Seção Regional Norte. http://www.oasrn.org/pdf_upload/el_espacio_ publico.pdf

Goikoetxea, J. (2018). Privatizar la democracia: Capitalismo global, política europea y Estado español. Barcelona: Icaria.

González, S. (2004). The role of the Guggenheim Museum in the development of urban entrepreneurial practices in Bilbao. International Journal of Iberian Studies, 16, 3, 177. https://doi.org/10.1386/ijis.16.3.177/1

Habermas, J. (1991). The Structural transformation of the public sphere: An inquiry into a category of bourgeois society. Cambridge: The MIT Press.

Harvey, D. (1973). Social justice and the City. London: Edward Arnold.

Harvey, D. (1982). The Limits to capital. Oxford: Basil Blackwell.

Harvey, D. (1990). The condition of postmodernity: An enquiry into the origins of cultural change. Oxford: Basil Blackwell.

Harvey, D. (2006). Notes towards a theory of uneven geographical development. In: Harvey, D (ed.) Spaces of Global Capitalism: A Theory of Uneven Geographical Development. 69 -116. London: Verso.

Harvey, D. (2012). Rebel cities: From the right to the city to the urban revolution. London: Verso.

Haussermann, H. \& Colomb, C. (2003). The New Berlin: Marketing the City of Dreams. In. Hoffman, L. M.; Fanstein, S.S. \& Judd, D.R. (eds.). Cities and Visitors: Regulating People, Markets, and City Space. Oxford: Blackwell.

Hobsbawm, E. J. (1962). The age of revolution: Europe, 17891848. New York: Mentor Book.

Jessop, B. (2016). The State: Past, Present and Future. Cambridge: Polity Press. https://doi.org/10.1002/wilm.10487

Judd, D. (2003). Visitors and the spatial ecology of the city. In Hoffman, L., Fainstein, S. \& Judd, D. (eds). Cities and visitors: Regulating people, markets, and city space. 23 - 38. Oxford: Blackwell. https://doi. org/10.1002/9780470773673.ch1

Khan, A. Z.; Moulaert, F; Schreurs, J.\& Miciukiewicz, K. (2014). Integrative Spatial Quality: A Relational Epistemology of Space and Transdisciplinarity. Urban Design and Planning, Journal of Urban Design, 19, (4). 393 - 411. https://doi.org/10.1080/13574809.2014.936142 
Lees, L. (2018). Comparative urbanism in gentrification studies: fashion or progress?. In Phillips, M., \& Lees, L. (eds.). Handbook of Gentrification Studies. Edward Elgar Publishing. https://doi.org/10.4337/9781785361746

Lees, L., Shin, H. B. \& Lopez, M. E. (2016). Planetary gentrification. Cambridge: Polity.

Lefebvre, H. (1969). Le Droit à la ville: 1. Paris: Anthropos.

Lefebvre, H. (1970). La révolution urbaine. Paris: Gallimard.

Lefebvre, H. (1974). La production de l'espace. Paris: Anthropos. https://doi.org/10.3406/homso.1974.1855

Ley, D. (1996): The New Middle Classes and the Remaking of the Central City. Oxford. Oxford University Press.

Ley, D. (2003). Artists, Aestheticisation and the Field of Gentrification. Urban Studies, 40, 12, 2527 - 2544. https:// doi.org/10.1080/0042098032000136192

Marmolejo, C. \& Stallbohm, M. (2008). En contra de la ciudad fragmentada: ¿hacia un cambio de paradigma urbanístico en la Región Metropolitana de Barcelona? Scripta Nova: Revista electrónica de geografía y ciencias sociales, 12, 270, $1-16$.

Massey, D. (1984). Spatial divisions of labour: Social structures and the geography of production. London: Macmillan.

Moulaert, F., \& Delladetsima, P. (2000). Globalization and integrated area development in European cities. Oxford: Oxford University Press.

Robertson, R. (1992). Globalization: Social theory and global culture. London: Sage

Rodríguez, A. (2002). Reinventar la ciudad: milagros y espejismos de la revitalización urbana en Bilbao. Universidad del País Vasco: Servicio de Publicaciones.

Rodríguez, A.; Abramo, P \& Vicario, L. (2015) A Model of Regeneration? Urban Redevelopment and Policyled Gentrification in Bilbao. In Rodríguez, A. \& Juaristi, J. (eds.). Transforming cities. Opportunities and Challenges of Urban Regeneration in the Basque Country. 21 - 50. University of Nevada \& University of the Basque Country: Center for the Basque Studies.

Rodríguez, A.; Martínez, E. Y Guenaga, G. (2001). Uneven Development. New Urban Policies and Socio-Spatial Fragmentation in Metropolitan Bilbao. European Urban and Regional Studies, 8, 2: 161-178. https://doi. org/10.1177/096977640100800206

Sassen, S. (1991). The Global City. NJ: Princeton University Press.

Sassen, S. (1993). Cities in a world economy. London: Sage

Sassen, S. (1996). Losing control?: Sovereignty in an age of globalization. New York: Columbia University Press.

Sassen, S. (2001). Impacts of information technologies on urban economies and politics. International Journal of Urban and Regional Research, 25, 411 - 418. https://doi. org/10.1111/1468-2427.00319
Smith, A. (2017). Animation or denigration? Using urban public spaces as event venues. Cognizant Communication Corporation. https://doi.org/10.3727/15259951 $7 X 15053272359068$

Smith, N. (1979). Toward a theory of gentrification: a back to the city movement by capital, not by people. Journal of the American Planning Association, 45 (4). 538 - 548. https:// doi.org/10.1080/01944367908977002

Smith, N. (1984). Uneven development: Nature, capital and the production of space. Oxford: Blackwell.

Smith, N. (2000). Gentrification. In Johnston, R.J., Gregory, D., Pratt, G. \& Watts, M. (eds.). The dictionary of human geography. 294 - 295. Oxford: Blackwell.

Smith, N. (2002). New Globalism, New Urbanism: Gentrification as Global Urban Strategy. Antipode, 34 (3), 427 - 450. https://doi.org/10.1111/1467-8330.00249

Soja, E. W. (2000). Postmetropolis: Critical studies of cities and regions. Oxford [u. a.]: Blackwell.

Swyngedouw, E. (1997). Neither global nor local: 'glocalisation' and the politics of scale. In Cox, K. (ed.). Spaces of globalization. New York: Guildford Press.

Topalov, C. (1979). La urbanización capitalista: Algunos elementos para su análisis. México: Edicol.

Topalov, C. (1984). Ganancias y rentas urbanas: Elementos teóricos. México: Siglo Veintiuno.

Vicario, L. \& Martinez, P. (2003). Another 'Guggenheim Effect'? The Generation of a Potentially Gentrifiable Neighbourhood in Bilbao. Urban Studies, 40, 2383 - 2400. https://doi.org/10.1080/0042098032000136129

Yin, R. K. (2009). Case study research: design and methods. In Applied social research methods (4th ed.). Los Angeles: Sage Publications.

\section{BIOGRAPHICAL NOTE}

\section{IAGO LEKUE LÓPEZ}

Graduated in Political Science and Administration and master's degree in Community Participation and Development (UPV / EHU). PhD candidate and member of the Department of Political Science and Administration at the University of the Basque Country (FPI) and member of the research group Parte Hartuz. Among his interest of research: urban and social structure; uneven development and scales; local governance; urban democracy. 